\title{
HIV/AIDS and viral hepatitis B/C co-infection during pregnancy
}

\author{
Carmen Georgescu", Mihai Mitran', Doru Pană', Loredana Mitran² \\ From The 9th Edition of the Scientific Days of the National Institute for Infectious Diseases Prof Dr Matei Bals \\ Bucharest, Romania. 23-25 October 2013
}

This co-infection is particularly serious in pregnancy through the following consequences: coagulation disorders caused by both diseases, as well as by the antiretroviral treatment (by pancytopenia, thrombocytopenia), and modification of uterine contractility through the intervention in contractile protein metabolism and secondary anemia, found in all cases.

Association with hepatic cytolysis and hepatocellular failure is the rule. In this association, hysterectomy necessary for hemostasis in some cases was imperative.

In our practice, we have encountered the HIV-hepatitis association in $30 \%$ of cases.

At birth, HIV/AIDS and hepatitis co-infection is a major risk factor for the mother, requiring total hysterectomy for hemostasis in $16.6 \%$ of the cases.

\section{Authors' details}

'Clinical Hospital of Obstetrics and Gynecology "Prof. Dr. Panait Sârbu", Bucharest, Romania. Elias University Emergency Hospital, Bucharest, Romania.

Published: 16 December 2013

\section{doi:10.1186/1471-2334-13-S1-P23}

Cite this article as: Georgescu et al:: HIV/AIDS and viral hepatitis B/C co-infection during pregnancy. BMC Infectious Diseases 2013 13(Suppl 1): P23.
Submit your next manuscript to BioMed Central and take full advantage of:

- Convenient online submission

- Thorough peer review

- No space constraints or color figure charges

- Immediate publication on acceptance

- Inclusion in PubMed, CAS, Scopus and Google Scholar

- Research which is freely available for redistribution 